Article

\title{
Luminescent Layered Double Hydroxides Intercalated with an Anionic Photosensitizer via the Memory Effect
}

\author{
Alexandre C. Teixeira ${ }^{1}$, Alysson F. Morais ${ }^{1} \mathbb{D}$, Ivan G.N. Silva ${ }^{1}$, Eric Breynaert ${ }^{2} \mathbb{D}$ and \\ Danilo Mustafa $1, * \mathbb{i}$ \\ 1 Instituto de Física da Universidade de São Paulo, São Paulo 05508-090, Brazil; \\ alexandre.candido.teixeira@usp.br (A.C.T.); afmorais@if.usp.br (A.F.M.); ingsilva@if.usp.br (I.G.N.S.) \\ 2 Center for Surface Chemistry and Catalysis (COK-KAT), KU Leuven, B-3001 Leuven, Belgium; \\ Eric.Breynaert@biw.kuleuven.be \\ * Correspondence: dmustafa@if.usp.br
}

Received: 12 February 2019; Accepted: 9 March 2019; Published: 14 March 2019

\begin{abstract}
Layered double hydroxides (LDHs) containing $\mathrm{Eu}^{3+}$ activators were synthesized by coprecipitation of $\mathrm{Zn}^{2+}, \mathrm{Al}^{3+}$, and $\mathrm{Eu}^{3+}$ in alkaline $\mathrm{NO}_{3}{ }^{-}$-rich aqueous solution. Upon calcination, these materials transform into a crystalline $\mathrm{ZnO}$ solid solution containing $\mathrm{Al}$ and $\mathrm{Eu}$. For suitably low calcination temperatures, this phase can be restored to $\mathrm{LDH}$ by rehydration in water, a feature known as the memory effect. During rehydration of an LDH, new anionic species can be intercalated and functionalized, obtaining desired physicochemical properties. This work explores the memory effect as a route to produce luminescent LDHs intercalated with 1,3,5-benzenetricarboxylic acid (BTC), a known anionic photosensitizer for $\mathrm{Eu}^{3+}$. Time-dependent hydration of calcined LDHs in a BTC-rich aqueous solution resulted in the recovery of the lamellar phase and in the intercalation with BTC. The interaction of this photosensitizer with $\mathrm{Eu}^{3+}$ in the recovered hydroxide layers gave rise to efficient energy transfer from the BTC antennae to the $\mathrm{Eu}^{3+}$ ions, providing a useful tool to monitor the rehydration process of the calcined LDHs.
\end{abstract}

Keywords: layered double hydroxide; memory effect; rare earth; europium; 1,3,5-benzenetricarboxylic acid

\section{Introduction}

Layered double hydroxides (LDHs), also called cationic clays, are a class of anion-exchange materials with a general chemical formula of $\left[\mathrm{M}^{\mathrm{II}}{ }_{1-\mathrm{x}} \mathrm{M}^{\mathrm{III}}{ }_{\mathrm{x}}(\mathrm{OH})_{2}\right]^{\mathrm{x}+}\left[\mathrm{A}^{\mathrm{n}-}{ }_{\mathrm{x} / \mathrm{n}}\right]^{\mathrm{x}-} \cdot \mathrm{yH}_{2} \mathrm{O}(\mathrm{M}$ : metal, $\mathrm{A}$ : anion). The isomorphic substitution of divalent metal cations $\left(\mathrm{M}^{\mathrm{II}}\right)$ in otherwise neutral brucite-like $\mathrm{M}^{\mathrm{II}}(\mathrm{OH})_{2}$ sheets with trivalent cations $\left(\mathrm{M}^{\mathrm{III}}\right)$ introduces positive charges in the hydroxide layers. In the overall LDH structure, these charges are compensated by the intercalation of anions $\left(\mathrm{A}^{\mathrm{n}-}\right)$ in the interlamellar space, as illustrated in Figure 1.

Synthetic LDHs exhibit a wide flexibility in their composition, as a score of metal cations and polyvalent anions can be introduced in the structure, tuning their chemico-physical properties [1-3]. By changing both the interlayer and the metal components, LDHs have been tuned towards different applications, serving as heterogeneous catalysts, catalyst supports [4], water treatment agents [5], luminescent materials [6-9], etc. 
Basal spacing (d)

Metallic layer

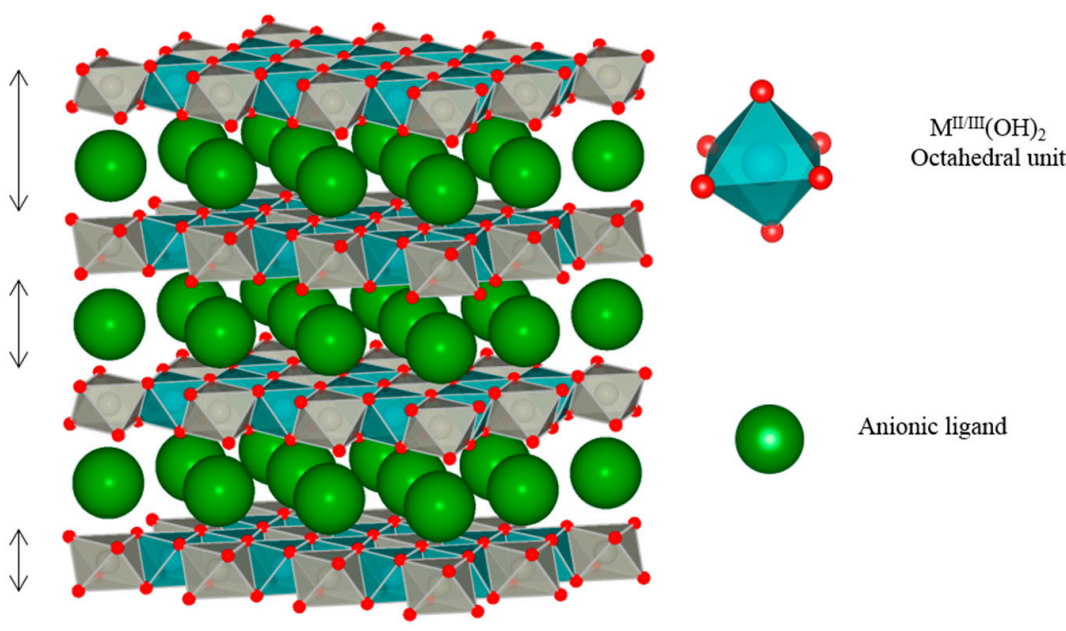

Figure 1. Layered double hydroxides (LDHs) are built up from sheets of $\left[\mathrm{M}^{\mathrm{II}}{ }_{1-x} \mathrm{M}^{\mathrm{III}}{ }_{\mathrm{x}}(\mathrm{OH})_{2}\right]^{\mathrm{x}+}$ octahedral units intercalated with anions. Each octahedron is formed from a metal cation $\left(\mathrm{M}^{\mathrm{II}}\right.$ or $\mathrm{M}^{\mathrm{III}}$ ) 6-coordinated to $\mathrm{OH}^{-}$groups (red spheres).

The introduction of trivalent rare earth elements $\left(\mathrm{RE}^{3+}\right)$ in $\mathrm{LDH}$ matrixes has revealed a series of $2 \mathrm{D}$ structured materials that have promising luminescent properties $[7,10]$. Rare earth elements form a subgroup of column 3 in the periodic table and exhibit very low influence of the ligand field in the energy of their spectral lines. This characteristic optical property results from the shielding of the $4 \mathrm{f}$ sub-shell by their filled $5 \mathrm{~d}$ and $6 \mathrm{~s}$ most external sub-shells [11,12]. Additionally, $\mathrm{RE}^{3+}$ ions present very low molar extinction coefficients because their $4 \mathrm{f}$ intraconfigurational transitions are forbidden, as demonstrated by Laporte's rule $(\Delta \ell= \pm 1)$. To increase the total observable luminescence, it is necessary to embed these elements in highly light-absorbing matrixes that serve as harvesting antennae, transferring the harvested energy to the luminescent center (antenna effect). This increases the excited state population of the $\mathrm{RE}^{3+}$, thereby increasing the overall luminescence [13-15].

The antenna effect has been demonstrated in RE-containing LDHs synthesized by direct coprecipitation with anionic antenna molecules or by exploiting anion exchange to intercalate anionic sensitizer ligands in the interlamellar space. A series of anionic sensitizers, including 4-biphenylacetate [8], sulfonates, and other carboxylates [16,17], have been intercalated in LDHs to incorporate $\mathrm{RE}^{3+}$ in their hydroxide layers. Several authors have also reported LDHs intercalated with $\mathrm{Eu}^{3+}$ complexes, where not only the ligand, but also the $\mathrm{RE}^{3+}$ is located in the interlamellar space $[6,18]$.

Controlled thermal decomposition of LDHs converts their structure into a mixed metal oxyhydroxide phase, before reaching a fully oxidic end product $[5,9,19,20]$. Starting from the oxyhydroxide phase, the lamellar LDH structure can be recovered by re-hydrating the product in aqueous solutions containing anions, a phenomenon known as the memory effect $[5,9,20-23]$. During this process, selective adsorption of dissolved anionic species $\mathrm{A}^{\mathrm{n}-}$ can efficiently occur, as indicated by the large anion exchange capacity observed for thermally treated samples [24]. The most frequently investigated application of the memory effect in LDHs involves the adsorption and subsequent removal of anionic dyes from waste water [5,25]. A less explored application is its use for the intercalation of anionic photosensitizing molecules.

The memory effect of the layered double hydroxides has been described in the literature for a large number of combinations of metal cations [21,23,26,27]. Different applications can be explored for different chemical compositions. For instance, Wong et al. [27] have shown that the memory effect of LDHs containing $\mathrm{Li}$ and $\mathrm{Al}$ can be used to sense water uptake in organic coatings. Ni et al. [25] have explored the memory effect of $\mathrm{Zn} / \mathrm{Al} \mathrm{LDHs}$ in the removal of methyl orange from aqueous solutions. Targeting environmental remediation, Gao et al. [23] have investigated the influence of humic acid on 
the memory effect of $\mathrm{Mg} / \mathrm{Al}$ and $\mathrm{Zn} / \mathrm{Al} \mathrm{LDH}$. The removal of boron species from waste water was also explored [28].

In this work, an underused strategy for generating luminescent LDHs via the memory effect was explored. The luminescent and structural properties of thermally treated $\left[\mathrm{Zn}_{2} \mathrm{Al}_{0.95} \mathrm{Eu}_{0.05}(\mathrm{OH})_{6}\right] \cdot\left(\mathrm{NO}_{3}{ }^{-}\right) \mathrm{LDHs}$ after hydration in the presence of 1,3,5-benzenetricarboxilate (BTC) were investigated. Calcination was performed at 350 and $600{ }^{\circ} \mathrm{C}$, followed by a time-dependent rehydration process in a BTC-rich aqueous solution, equilibrating the samples over a period between $1 \mathrm{~min}$ and 5 days. The resulting hydrated phases were characterized by both powder X-ray diffraction and luminescence spectroscopy.

\section{Materials and Methods}

$\mathrm{H}_{3} \mathrm{BTC}\left(97 \mathrm{~mol} \%\right.$, Sigma-Aldrich), $\mathrm{Zn}\left(\mathrm{NO}_{3}\right)_{2} \cdot 6 \mathrm{H}_{2} \mathrm{O}$ (98 mol\%, Vetec), $\mathrm{Al}\left(\mathrm{NO}_{3}\right)_{3} \cdot 9 \mathrm{H}_{2} \mathrm{O}(98 \mathrm{~mol} \%$, LabSynth), and $\mathrm{NaOH}\left(97 \mathrm{~mol} \%\right.$, Vetec) were used without further purification. $\mathrm{Eu}\left(\mathrm{NO}_{3}\right)_{3} \cdot 6 \mathrm{H}_{2} \mathrm{O}$ was prepared by dissolving $\mathrm{Eu}_{2} \mathrm{O}_{3}$ (CSTARM, 99,99 mol\%) in concentrated nitric acid, which led to the subsequent crystallization of $\mathrm{Eu}\left(\mathrm{NO}_{3}\right)_{3} \cdot 6 \mathrm{H}_{2} \mathrm{O}$ in accordance to the procedure described by Silva et al. [29].

\subsection{Sample Preparation}

Layered double hydroxides with nominal molar composition $\left[\mathrm{Zn}_{2} \mathrm{Al}_{0.95} \mathrm{Eu}_{0.05}(\mathrm{OH})_{6}\right] \cdot\left(\mathrm{NO}_{3}{ }^{-}\right)$ $\left(\mathrm{ZnAlEu}-\mathrm{NO}_{3} \mathrm{LDH}\right)$ and $\left[\mathrm{Zn}_{2} \mathrm{Al}_{0.95} \mathrm{Eu}_{0.05}(\mathrm{OH})_{6}\right] \cdot\left(\mathrm{BTC}^{3-}\right)_{0.33}(\mathrm{ZnAlEu}-\mathrm{BTC} \mathrm{LDH})$ were synthesized by coprecipitation. A volume of $10 \mathrm{~mL}$ of a $1 \mathrm{~mol} \mathrm{~L}^{-1}$ solution containing the metal precursors $\mathrm{Zn}\left(\mathrm{NO}_{3}\right)_{2} \cdot 6 \mathrm{H}_{2} \mathrm{O}, \mathrm{Al}\left(\mathrm{NO}_{3}\right)_{2} \cdot 9 \mathrm{H}_{2} \mathrm{O}$, and $\mathrm{Eu}\left(\mathrm{NO}_{3}\right)_{2} \cdot 6 \mathrm{H}_{2} \mathrm{O}$ in the ratio 2:0.95:0.05 was added dropwise $\left(\sim 10 \mathrm{~mL} \mathrm{~h}^{-1}\right)$ to $200 \mathrm{~mL}$ of an alkaline ( $\left.\mathrm{pH} 8\right)$ solution containing the dissolved ligands. During the synthesis, this solution was continuously stirred, purged with $\mathrm{N}_{2(\mathrm{~g})}$, and $\mathrm{pH}$-stated at $\mathrm{pH} 8$ using an automatic titrator (Metrohm 785 DMP Titrino). The resulting suspension was equilibrated in a closed vessel at $60^{\circ} \mathrm{C}$ for two days, followed by centrifugation and subsequent rinsing with distilled water. The resulting solid phase was dried in air at $60^{\circ} \mathrm{C}$ for three days.

For the LDHs intercalated with $\mathrm{NO}_{3}{ }^{-}$, the nitrate anions originated from the precursor metal salts. For LDHs intercalated with BTC ${ }^{3-}$, the amount of BTC $\left(2.3 \times 10^{-3} \mathrm{~mol}\right)$ was chosen to exceed the positive charges in the hydroxide layers by a factor of at least 2, with $\mathrm{BTC} / \mathrm{Al}=2: 3$.

Calcination of the dried $\mathrm{ZnAlEu}-\mathrm{NO}_{3} \mathrm{LDHs}$ was performed by heating the $\mathrm{LDH}$ in a muffle furnace for four hours at, respectively, $200{ }^{\circ} \mathrm{C}$ (C-LDH-200), $350{ }^{\circ} \mathrm{C}$ (C-LDH-350), or $600{ }^{\circ} \mathrm{C}$ (C-LDH-600), ramping up the oven temperature from ambient to the final temperature at a rate of $5{ }^{\circ} \mathrm{C} \mathrm{min}^{-1}$.

Rehydration of the calcined samples was achieved by suspending $100 \mathrm{mg}$ of the calcined LDHs in $10 \mathrm{~mL}$ of a $12 \mathrm{mmol} \mathrm{L}^{-1}$ BTC aqueous solution. This solution was prepared by dissolving BTC in a heated $\left(60^{\circ} \mathrm{C}\right)$ aqueous solution, subsequently titrated with a $1 \mathrm{M} \mathrm{NaOH}$ solution (ca. $0.3 \mathrm{~mL}$ ) to finally reach a $\mathrm{pH}$ between 3.5 and 4.0. Rehydration of the $\mathrm{LDH}$ was performed under continuous stirring ( $\sim 300 \mathrm{rpm})$, varying the rehydration time from $1 \mathrm{~min}$ up to five days.

\subsection{Characterization}

A thermogravimetric analysis was performed on $13 \mathrm{mg}$ of the $\mathrm{ZnAlEu}-\mathrm{NO}_{3} \mathrm{LDH}$ using a TGA Q500 (TA Instruments, New Castle, DE, USA), by ramping up the temperature from room temperature to $800{ }^{\circ} \mathrm{C}$ at a rate of $5{ }^{\circ} \mathrm{C} \mathrm{min}^{-1}$ using an air flow of $60 \mathrm{~mL} \mathrm{~min}^{-1}$.

Powder X-ray diffraction (PXRD) analyses were performed using a D8 Discover (Bruker, Atibaia, Brazil) diffractometer in Bragg-Brentano geometry using $\mathrm{Cu}$ K $\alpha$ radiation $(\lambda=1.5418 \AA$ ). Data were recorded from $4^{\circ}$ to $70^{\circ} 2 \theta$ in steps of $0.05^{\circ}$ using an integration time of $1 \mathrm{~s}$.

Luminescence spectra were obtained on a SPEX ${ }^{\circledR}$ Fluorolog ${ }^{\circledR} 3$ (Horiba, São Paulo, SP, Brazil) equipped with a $450 \mathrm{~W}$ Xenon lamp as an excitation source. 


\section{Results and Discussion}

X-ray diffraction patterns of the as-prepared $\mathrm{ZnAlEu}-\mathrm{NO}_{3} \mathrm{LDHs}$ (Figure $2 \mathrm{~A}$ ) readily revealed the characteristic (003) and (006) basal reflections at $9.90^{\circ}$ and $19.85^{\circ} 2 \theta$, which indicated a basal spacing (see Figure 1) of $8.96 \AA$, typical for $\mathrm{NO}_{3}{ }^{-}$-intercalated LDHs [30]. From the partially overlapped (110) and (113) reflections around $60.452 \theta$, the metal-to-metal distance within the hydroxide layers could also be estimated as ' $\mathrm{a}=2 \mathrm{~d}_{(110)}=3.06 \AA^{\prime}$ [3]. The (00l) basal reflections of the ZnAlEu-BTC LDHs at $6.6^{\circ}, 13.2^{\circ}, 20.2^{\circ}$, and $26.2^{\circ} 2 \theta$ confirmed the basal spacing of $13.4 \AA$ previously reported for BTC-intercalated LDHs (as illustrated in Figure 2C) [7].
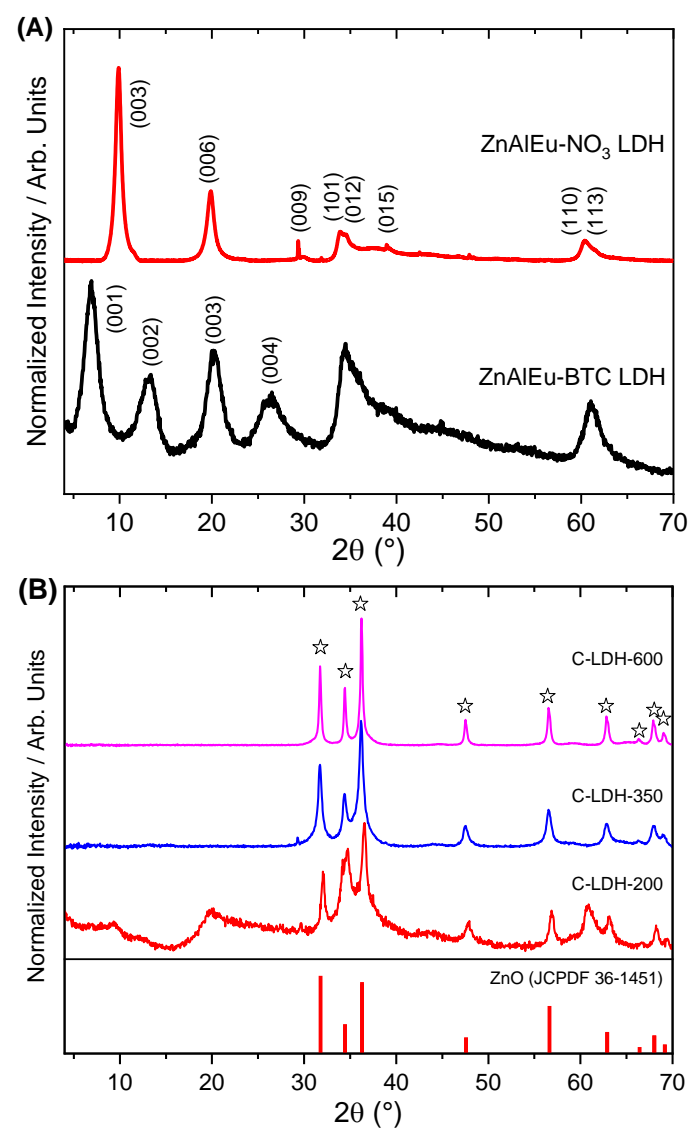

(C)

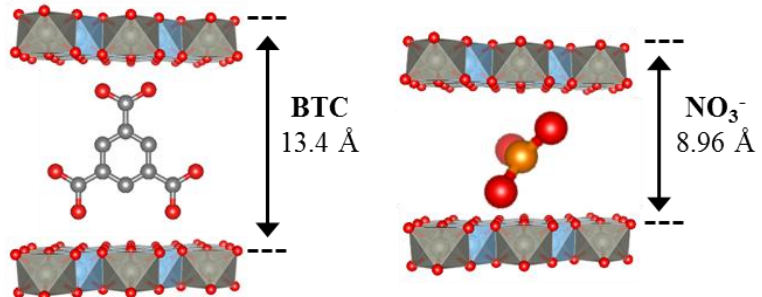

Figure 2. Powder X-ray diffraction patterns of (A) the as-prepared ZnAlEu LDHs and (B) $\mathrm{ZnAlEu}-\mathrm{NO}_{3}$ LDHs calcined at $200{ }^{\circ} \mathrm{C}$ (C-LDH-200), $350{ }^{\circ} \mathrm{C}$ (C-LDH-350), and $600{ }^{\circ} \mathrm{C}$ (C-LDH-600). Starred peaks are related to the formation of a $\mathrm{ZnO}$-like phase. The diffractogram of $\mathrm{ZnO}$ is shown for comparison. (C) Intercalation scheme and basal spacing for LDHs with 1,3,5-benzenetricarboxilate (BTC) and $\mathrm{NO}_{3}{ }^{-}$[30].

LDHs can be dehydrated and dehydroxylated by calcination at temperatures as low as $200{ }^{\circ} \mathrm{C}$ [31]. For the $\mathrm{ZnAlEu}-\mathrm{NO}_{3} \mathrm{LDHs}$, thermogravimetric analysis showed three main mass loss events (Figure 3). The first one, centered around $90{ }^{\circ} \mathrm{C}$, is related to the desorption of physisorbed and weakly bound surface water. A more pronounced mass loss was observed at $220^{\circ} \mathrm{C}$, related to the removal of crystal water, the dehydroxylation of vicinal $\mathrm{OH}$ groups within the same layer, and the subsequent 
condensation of $\mathrm{OH}$ groups from adjacent layers when the layer structure collapsed. At this time, a mixed metal oxyhydroxide phase was obtained, containing a series of oxygen sites $\mathrm{O}^{2-}{ }_{\text {(C-LDH) }}$ and oxygen vacancies resulting from the following endothermic transformation [21], which occurred above $180^{\circ} \mathrm{C}$ :

$$
2 \mathrm{OH}^{-}{ }_{(\mathrm{LDH})} \rightarrow \mathrm{H}_{2} \mathrm{O}_{(\mathrm{g})}+\mathrm{O}^{2-}{ }_{(\mathrm{C}-\mathrm{LDH})}
$$

The PXRD pattern of the sample calcined at $200^{\circ} \mathrm{C}$ (C-LDH-200) (Figure 2B) indicated the formation of a ZnO-like phase. The disappearance of the basal reflections of the LDHs with the retention of the partially overlapped (110) and (113) reflections indicated the collapse of the layers, but with incomplete dehydroxylation (as illustrated in Figure 4).

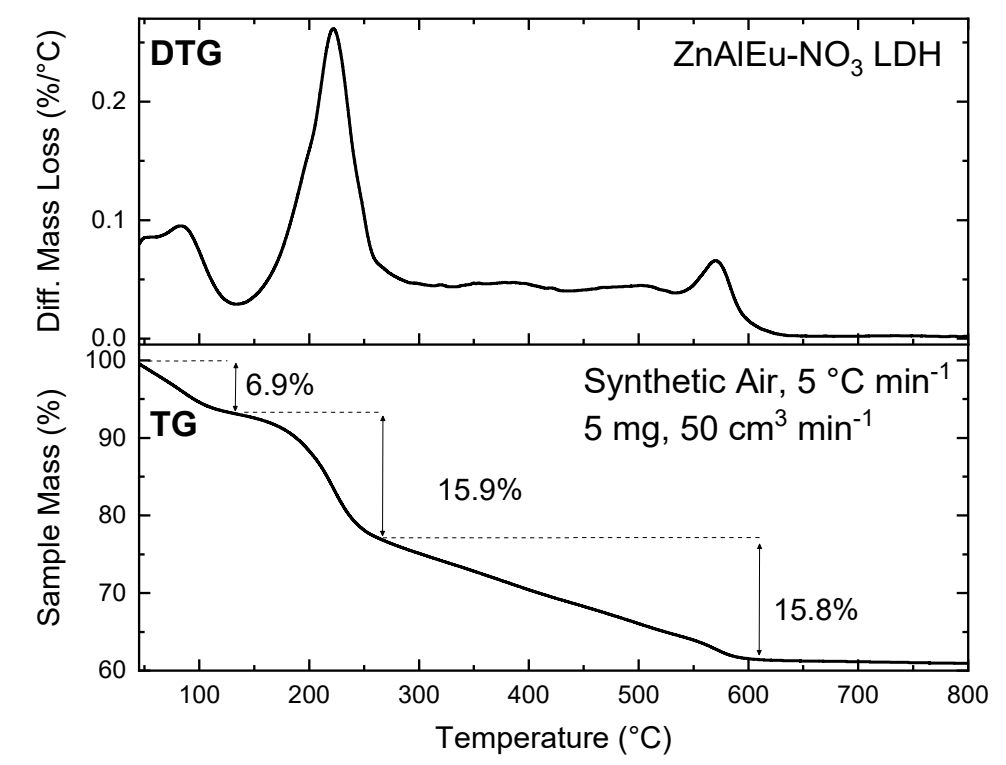

Figure 3. Thermogravimetric analysis of the $\mathrm{ZnAlEu}-\mathrm{NO}_{3} \mathrm{LDHs}$.

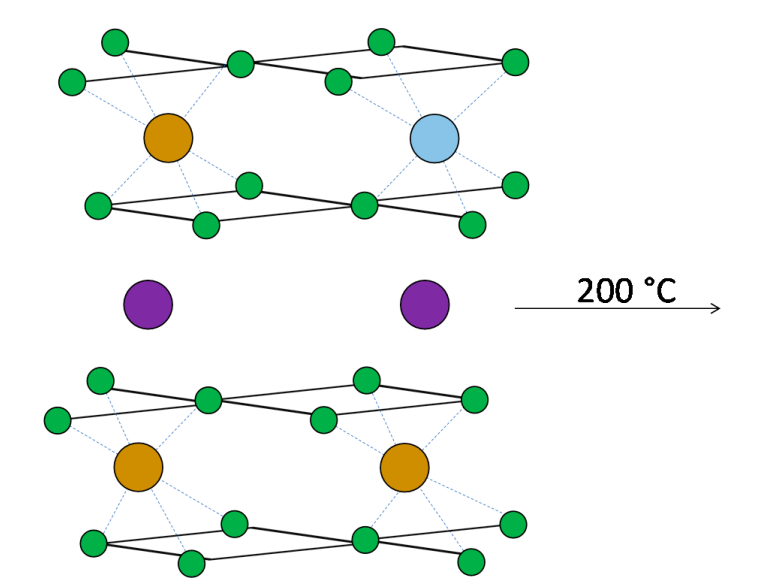

$\mathrm{O}-\mathrm{H} \bigcirc \mathrm{O} \bigcirc \mathrm{Zn}$

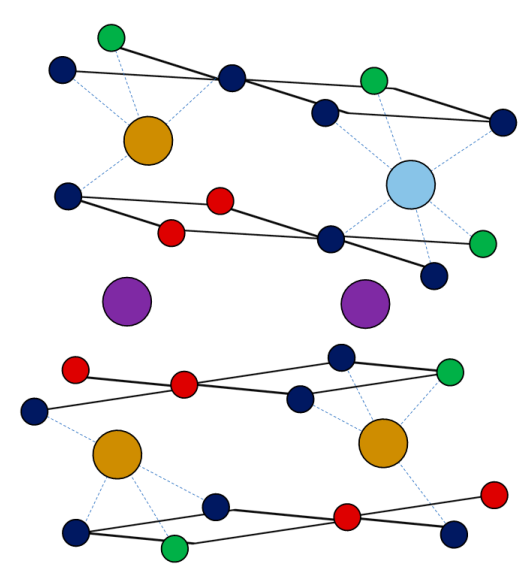

Vacancy
Interlayer content

Figure 4. Schematic overview of the dehydroxylation of LDHs at low temperatures.

The final mass loss event observed in the TGA over a broad temperature range from 300 to $620^{\circ} \mathrm{C}$ (Figure 3) was assigned to further dehydroxylation, continuous decomposition, and release of the intercalated $\mathrm{NO}_{3}{ }^{-}$. As described by Valente et al. [32], the extent of this last event is related to the close packing induced by the collapse of the interlayer structure, thereby hindering the release of the interlayer products. The experimental mass loss observed at $600{ }^{\circ} \mathrm{C}$ in the TG experiment is in 
agreement with a theoretical loss of $16 \mathrm{wt} \%$ that was expected upon dehydroxylation and complete removal of $\mathrm{NO}_{3}{ }^{-}$from a $\left[\mathrm{Zn}_{2} \mathrm{Al}_{0.95} \mathrm{Eu}_{0.05}(\mathrm{OH})_{6}\right] \cdot\left(\mathrm{NO}_{3}\right) \cdot\left(\mathrm{H}_{2} \mathrm{O}\right) \mathrm{LDH}$ phase.

By calcining $\mathrm{ZnAlEu}-\mathrm{NO}_{3} \mathrm{LDH}$ at $350{ }^{\circ} \mathrm{C}$, i.e., above the second mass loss event in the thermogravimetric analysis (Figure 3), the material was converted into $\mathrm{ZnO}$-like crystals, exhibiting no signs of segregation of crystalline $\mathrm{Al}_{2} \mathrm{O}_{3}$ or $\mathrm{Eu}_{2} \mathrm{O}_{3}$ [33]. Some authors attribute the absence of diffraction lines for $\mathrm{Al}_{2} \mathrm{O}_{3}$ or $\mathrm{Eu}_{2} \mathrm{O}_{3}$ to the formation of a $\mathrm{ZnO}$-based solid solution embedding the trivalent ions [34-36]. Even upon calcination at $600{ }^{\circ} \mathrm{C}$, no indication for $\mathrm{Al}_{2} \mathrm{O}_{3}$ or $\mathrm{Eu}_{2} \mathrm{O}_{3}$ could be observed.

Figure 5 shows the evolution of the X-ray diffraction patterns as a function of the rehydration time of calcined LDHs suspended BTC-rich aqueous solutions. Overall, this rehydration process can be expressed by the following equation [23]:

$$
\mathrm{M}^{\mathrm{II}}{ }_{1-\mathrm{x}} \mathrm{M}^{\mathrm{III}}{ }_{\mathrm{x}} \mathrm{O}_{1+\mathrm{x} / 2}+(\mathrm{x} / \mathrm{n}) \mathrm{A}^{\mathrm{n}-}+(\mathrm{m}+1+\mathrm{x} / 2) \mathrm{H}_{2} \mathrm{O} \rightarrow \mathrm{M}_{1-\mathrm{x}}^{\mathrm{II}} \mathrm{M}^{\mathrm{III}}(\mathrm{OH})_{2}\left(\mathrm{~A}^{\mathrm{n}-}\right)_{\mathrm{x} / \mathrm{n}} \cdot \mathrm{mH}_{2} \mathrm{O}+\mathrm{xOH}^{-}
$$

For samples calcined at $350^{\circ} \mathrm{C}$ (Figure 5 left), the emergence of the reflection at $9.90^{\circ} 2 \theta$ indicated a recovery of a lamellar structure after $1 \mathrm{~min}$ of rehydration. As described by Valente et al. [32], $\mathrm{NO}_{3}{ }^{-}$could become partially confined upon the collapse of the LDH structure, which could assist the recovery of the structure upon rehydration. After $30 \mathrm{~min}$, BTC started to become intercalated in the previously recovered layered phase. The $(00 l)$ basal reflections of the recovered BTC-intercalated lamellar phase presented a slight shift to higher $2 \theta$, indicating that the as-synthesized and recovered phases possessed different hydration contents. After three days of rehydration, the reflections resulting from the oxide phase broadened considerably, which indicated a breakdown of the oxide domains in the sample.
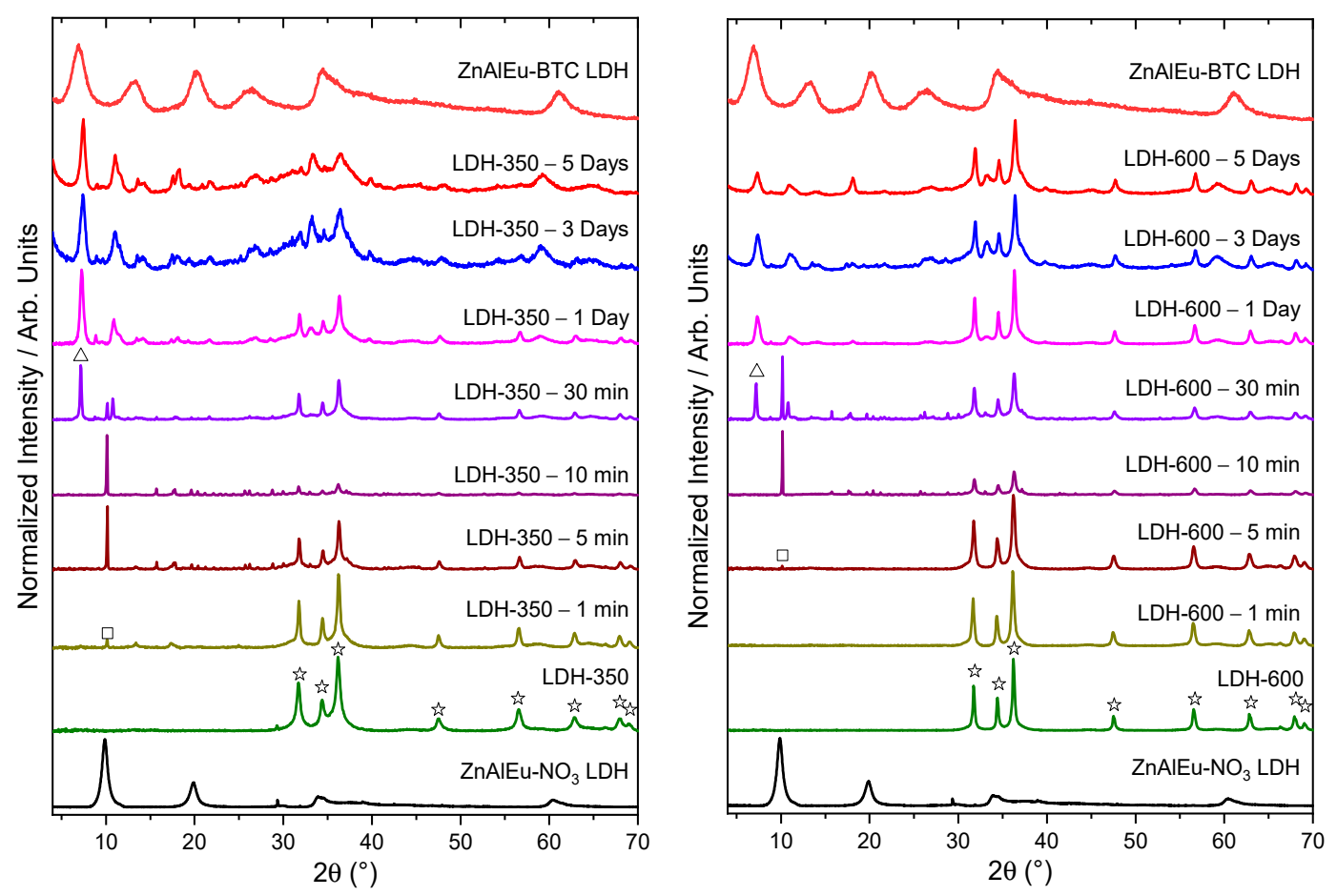

Figure 5. Powder $\mathrm{X}$-ray diffraction patterns for different hydration times of $\mathrm{ZnAlEu}-\mathrm{NO}_{3} \mathrm{LDH}$ samples calcined at $350{ }^{\circ} \mathrm{C}$ (left) and $600{ }^{\circ} \mathrm{C}$ (right). Starred peaks relate to the formation of a $\mathrm{ZnO}$ phase. Reflections associated with the reappearance of a layered phase are marked with open squares, while the basal reflections of LDH intercalated with BTC $\left(7.0^{\circ}, 12.7 \AA\right)$ are marked with an open triangle. The PXRD patters of the samples $\mathrm{ZnAlEu}-\mathrm{NO}_{3} \mathrm{LDH}$ and $\mathrm{ZnAlEu}-\mathrm{BTC} \mathrm{LDH}$ are shown for comparison. 
For specimens treated at $600{ }^{\circ} \mathrm{C}$ (Figure 5 right), the recovery of the lamellar phase was delayed compared to that of samples treated at $350{ }^{\circ} \mathrm{C}$. After five days, a lower degree of regeneration was observed for the LDH calcined at $600{ }^{\circ} \mathrm{C}$ (C-LDH-600).

The photoluminescence properties of the samples were investigated by measuring their excitation and emission spectra (Figure 6). The excitation spectra (Figure 6 left) of all samples were collected at room temperature, monitoring the $\left(\mathrm{Eu}^{3+}\right)^{5} \mathrm{D}_{0} \rightarrow{ }^{7} \mathrm{~F}_{2}$ emission at $614 \mathrm{~nm}$. In the calcined samples, no zinc oxide $\mathrm{O}^{2-} \rightarrow \mathrm{Eu}^{3+}$ Ligand-to-Metal-Charge Transfer band (LMCT) was found, in accordance to other studies of $\mathrm{Eu}^{3+}$-doped $\mathrm{ZnO}$ [37]. In the hydrated materials, the broad excitation band in the higher energy region (235-315 nm) was composed by two bands owing to the energy transference from the BTC to $\mathrm{Eu}^{3+}$. One band was centered around $265 \mathrm{~nm}$ and was attributed to (BTC) $\mathrm{O}^{2-} \rightarrow \mathrm{Eu}^{3+}$ LMCT [29,38-40]. The other band, centered at $290 \mathrm{~nm}$, corresponded to the BTC singlet transition $\mathrm{S}_{0} \rightarrow \mathrm{S}_{\mathrm{n}}[41-43]$ with subsequent energy transfer to $\mathrm{Eu}^{3+}$.
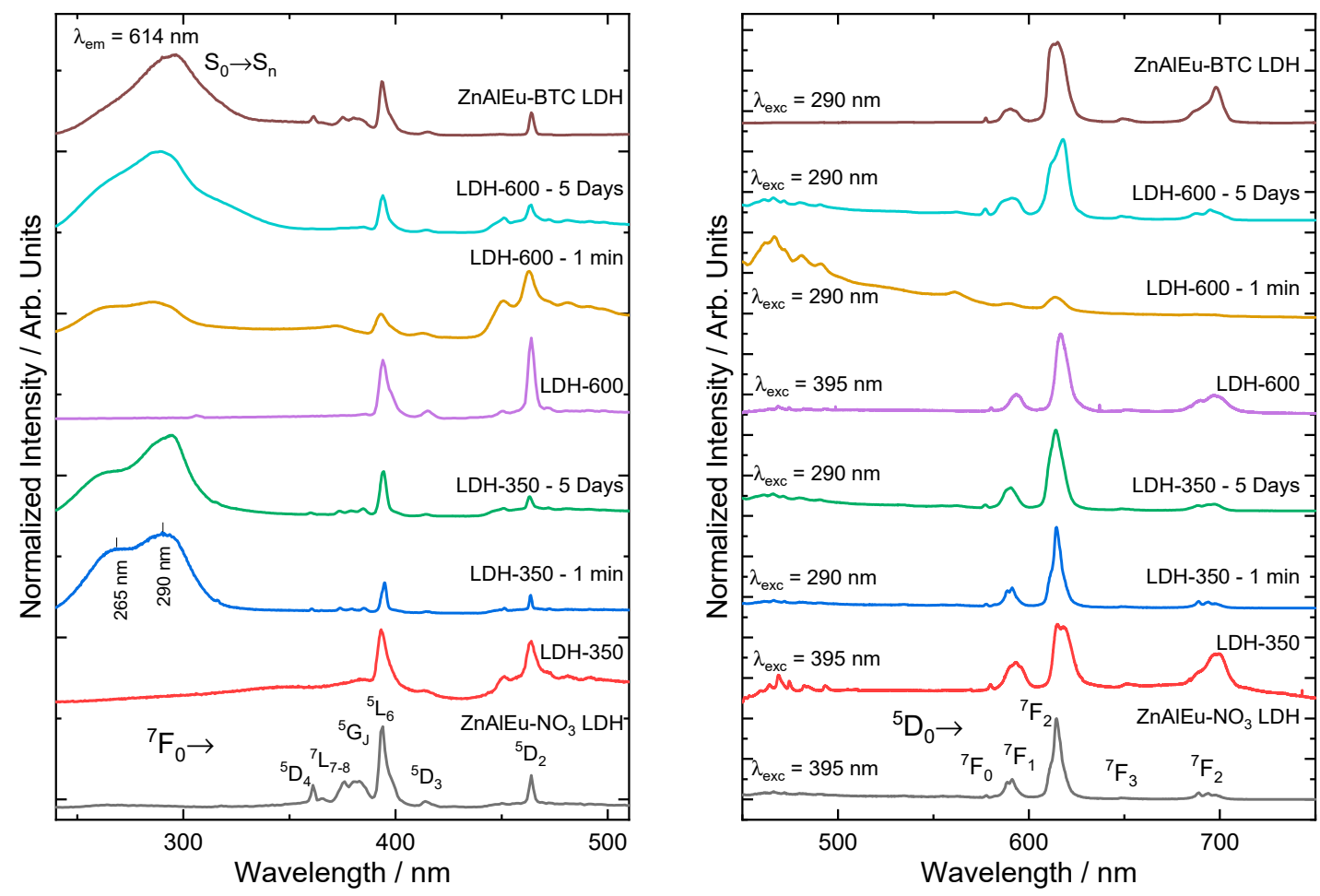

Figure 6. (left) Normalized excitation spectra recorded at $300 \mathrm{~K}$, monitoring the $\left(\mathrm{Eu}^{3+}\right)^{5} \mathrm{D}_{0} \rightarrow{ }^{7} \mathrm{~F}_{2}$ emission at $614 \mathrm{~nm}$ of the $\mathrm{ZnAlEu}-\mathrm{NO}_{3} \mathrm{LDH}$ (as-prepared) together with the calcined and rehydrated samples. (right) Normalized emission spectra (300 K) under excitation at the BTC ligand-to-metal transference band $(290 \mathrm{~nm})$ for the rehydrated samples and under excitation at the $\left(\mathrm{Eu}^{3+}\right)^{7} \mathrm{~F}_{0} \rightarrow{ }^{5} \mathrm{~L}_{6}$ excitation band at $395 \mathrm{~nm}$ for the as-prepared and calcined samples. The labels of the $4 \mathrm{f}-4 \mathrm{f}$ intraconfigurational transitions of $\mathrm{Eu}^{3+}$ are shown. The spectra of the sample ZnAlEu-BTC LDH are shown for comparison.

The emission spectrum under direct excitation of the $\left(\mathrm{Eu}^{3+}\right){ }^{7} \mathrm{~F}_{0} \rightarrow{ }^{5} \mathrm{~L}_{6}$ excitation band $(395 \mathrm{~nm})$ of the as-synthesized $\mathrm{ZnAlEu}-\mathrm{NO}_{3} \mathrm{LDHs}$ (Figure 6 right) showed the characteristic emission bands of $\mathrm{Eu}^{3+}$. Similar emission spectra were observed for the samples calcined at 350 and $600{ }^{\circ} \mathrm{C}$, but with broader emission bands (especially for C-LDH-350). The broadening of the emission bands arose from slightly different sites occupied by $\mathrm{Eu}^{3+}$ in the matrix, which produced slightly different emission profiles [44]. This indicated that the number of sites occupied by $\mathrm{Eu}^{3+}$ increased after calcination. Compared to the ${ }^{5} \mathrm{D}_{0} \rightarrow{ }^{7} \mathrm{~F}_{1}$ transition, the higher intensity of the ${ }^{5} \mathrm{D}_{0} \rightarrow{ }^{7} \mathrm{~F}_{2}$ transition was enabled by forced electric dipole [45-48], which indicated the absence of inversion symmetry around the average $\mathrm{Eu}^{3+}$ site. 
After rehydrating in a BTC-rich aqueous solution, the calcined samples started to recover their lamellar structure. At the same time, these samples also started to transfer energy from the BTC antenna to $\mathrm{Eu}^{3+}$. Figure 6 shows the emission spectra under excitation of the BTC $\mathrm{S}_{0} \rightarrow \mathrm{S}_{\mathrm{n}}$ transition after time-dependent hydration of the samples C-LDH-350 and C-LDH-600. Although no intercalation with BTC was found after hydrating the sample C-LDH-350 for $1 \mathrm{~min}$, the photosensitizer was still able to transfer energy to $\mathrm{Eu}^{3+}$. This effect was probably due to BTC molecules adsorbed on the outer surface of the particles, which recovered to the LDH phase faster than the bulk [23]. This effect was seen in the sample C-LDH-600 only for longer hydration times, which indicated that the rehydration of this sample was less efficient than that of C-LDH-350, as was also inferred from the PXRD results.

\section{Conclusions}

In summary, to produce luminescent $\mathrm{LDH}$ phases, $\mathrm{ZnAlEu}-\mathrm{NO}_{3} \mathrm{LDHs}$ calcined at up to $600{ }^{\circ} \mathrm{C}$ can only partially be restored to the LDH phase through rehydration in BTC-rich aqueous solutions. The calcination temperature appears to be an important factor for an efficient rehydration, as samples calcined at $350{ }^{\circ} \mathrm{C}$ showed a higher degree of regeneration compared to those treated at $600{ }^{\circ} \mathrm{C}$. For samples treated at $350^{\circ} \mathrm{C}$, the recovery of the $\mathrm{LDH}$ structure started after $1 \mathrm{~min}$ of rehydration, while for the samples treated at $600{ }^{\circ} \mathrm{C}$ the regeneration only started after $5 \mathrm{~min}$. After $30 \mathrm{~min}$, the $\mathrm{pH}$ of the rehydration solution increased as a result of the dissolution of the oxides, and this facilitated the intercalation of BTC. The interaction of this photosensitizer with $\mathrm{Eu}^{3+}$ in the recovered hydroxide layers gave rise to efficient energy transfer from the BTC antenna molecule to the $\mathrm{Eu}^{3+}$ ions, which proved to be a useful tool to monitor the rehydration process of the calcined LDHs.

Author Contributions: Conceptualization, E.B. and D.M.; methodology, A.F.M., I.G.N.S., E.B. and D.M.; validation, A.C.T. and A.F.M.; formal analysis, A.C.T, A.F.M. and I.G.N.S.; investigation, A.C.T., A.F.M. and I.G.N.S.; resources, D.M.; data curation, A.C.T., A.F.M., I.G.N.S. and D.M.; writing-original draft preparation, A.F.M., I.G.N.S., E.B. and D.M.; writing—review and editing, A.F.M., I.G.N.S., E.B. and D.M.; visualization, A.F.M. and I.G.N.S.; supervision, E.B. and D.M.; project administration, D.M.; funding acquisition, D.M.

Funding: This research was funded by Fundação de Amparo à Pesquisa do Estado de São Paulo (FAPESP, 2015/19210-0), Coordenação de Aperfeiçoamento de Pessoal de Nível Superior (CAPES, 1723707, Finance Code 001), and Conselho Nacional de Desenvolvimento Científico e Tecnológico (CNPq, 142127/2014-0 and 403055/2016-4).

Acknowledgments: The authors acknowledge the Laboratory of Crystallography (IFUSP, São Paulo) for assistance with the PXRD measurements.

Conflicts of Interest: The authors declare no conflict of interest.

\section{References}

1. Nalawade, P.; Aware, B.; Kadam, V.J.; Hirlekar, R.S. Layered double hydroxides: A review. J. Sci. Ind. Res. 2009, 68, 267-272.

2. Khan, A.I.; O'Hare, D. Intercalation chemistry of layered double hydroxides: recent developments and applications. J. Mater. Chem. 2002, 12, 3191-3198. [CrossRef]

3. Duan, X.; Evans, D.G.; He, J.; Kang, Y.; Khan, A.I.; Leroux, F.; Li, B.; Li, F.; O’Hare, D.; Slade, R.C.T.; et al. Structure and Bonding_Layered Double Hydroxides, 1st ed.; Duan, X., Evans, D.G., Eds.; Springer: Berlin/Heidelberg, Germany, 2005; Volume 119, ISBN 3-540-28279-3.

4. Fan, G.; Li, F.; Evans, D.G.; Duan, X. Catalytic applications of layered double hydroxides: recent advances and perspectives. Chem. Soc. Rev. 2014, 43, 7040-7066. [CrossRef] [PubMed]

5. Santos, R.M.M.; Tronto, J.; Briois, V.; Santilli, C.V. Thermal decomposition and recovery properties of $\mathrm{ZnAl}-\mathrm{CO}_{3}$ layered double hydroxide for anionic dye adsorption: insight into the aggregative nucleation and growth mechanism of the LDH memory effect. J. Mater. Chem. A 2017, 5, 9998-10009. [CrossRef]

6. Sarakha, L.; Forano, C.; Boutinaud, P. Intercalation of luminescent Europium(III) complexes in layered double hydroxides. Opt. Mater. 2009, 31, 562-566. [CrossRef] 
7. Morais, A.F.; Silva, I.G.N.; Sree, S.P.; de Melo, F.M.; Brabants, G.; Brito, H.F.; Martens, J.A.; Toma, H.E.; Kirschhock, C.E.A.; Breynaert, E.; et al. Hierarchical self-supported ZnAlEu LDH nanotubes hosting luminescent CdTe quantum dots. Chem. Commun. 2017, 53, 7341-7344. [CrossRef] [PubMed]

8. Gunawan, P.; Xu, R. Lanthanide-doped layered double hydroxides intercalated with sensitizing anions: Efficient energy transfer between host and guest layers. J. Phys. Chem. C 2009, 113, 17206-17214. [CrossRef]

9. Zhao, Y.; Li, J.-G.; Fang, F.; Chu, N.; Ma, H.; Yang, X. Structure and luminescence behaviour of as-synthesized, calcined, and restored MgAlEu-LDH with high crystallinity. Dalt. Trans. 2012, 41, 12175. [CrossRef] [PubMed]

10. Zhuravleva, N.G.; Eliseev, A.A.; Lukashin, A.V.; Kynast, U.; Tretyakov, Y.D. Energy transfer in luminescent $\mathrm{Tb}$ - and Eu-containing layered double hydroxides. Mendeleev Commun. 2004, 14, 176-178. [CrossRef]

11. Meggers, W.F. Electron configurations of "rare-earth" elements. Science 1947, 105, 514-516. [CrossRef] [PubMed]

12. Biggemann, D.; Mustafa, D.; Tessler, L.R. Photoluminescence of Er-doped silicon nanoparticles from sputtered $\mathrm{SiO}_{\mathrm{x}}$ thin films. Opt. Mater. 2006, 28, 842-845. [CrossRef]

13. Binnemans, K. Lanthanide-based luminescent hybrid materials. Chem. Rev. 2009, 109, 4283-4374. [CrossRef] [PubMed]

14. Binnemans, K. Interpretation of europium(III) spectra. Coord. Chem. Rev. 2015, 295, 1-45. [CrossRef]

15. Mustafa, D.; Biggemann, D.; Martens, J.A.; Kirschhock, C.E.A.; Tessler, L.R.; Breynaert, E. Erbium enhanced formation and growth of photoluminescent Er/Si nanocrystals. Thin Solid Films 2013, 536, 196-201. [CrossRef]

16. Gao, X.; Hu, M.; Lei, L.; O’Hare, D.; Markland, C.; Sun, Y.; Faulkner, S. Enhanced luminescence of europium-doped layered double hydroxides intercalated by sensitiser anions. Chem. Commun. 2011, 47, 2104-2106. [CrossRef] [PubMed]

17. Zhang, Z.; Chen, G.; Liu, J. Tunable photoluminescence of europium-doped layered double hydroxides intercalated by coumarin-3-carboxylate. RSC Adv. 2014, 4, 7991. [CrossRef]

18. Gago, S.; Pillinger, M.; Sá Ferreira, R.A.; Carlos, L.D.; Santos, T.M.; Gonçalves, L.S. Immobilization of Lanthanide Ions in a Pillared Layered Double Hydroxide. Chem. Mater. 2005, 17, 5803-5809. [CrossRef]

19. Bharali, P.; Saikia, R.; Boruah, R.K.; Goswamee, R.L. A comparative study of thermal decomposition behaviour of $\mathrm{Zn}-\mathrm{Cr}, \mathrm{Zn}-\mathrm{Cr}-\mathrm{Al}$ and $\mathrm{Zn}-\mathrm{Al}$ type layered double hydroxides. J. Therm. Anal. Calorim. 2004, 78, 831-838. [CrossRef]

20. Kowalik, P.; Konkol, M.; Kondracka, M.; Próchniak, W.; Bicki, R.; Wiercioch, P. Memory effect of the CuZnAl-LDH derived catalyst precursor - In situ XRD studies. Appl. Catal. A Gen. 2013, 464-465, 339-347. [CrossRef]

21. Marchi, A.J.; Apesteguía, C.R. Impregnation-induced memory effect of thermally activated layered double hydroxides. Appl. Clay Sci. 1998, 13, 35-48. [CrossRef]

22. Klemkaite, K.; Prosycevas, I.; Taraskevicius, R.; Khinsky, A.; Kareiva, A. Synthesis and characterization of layered double hydroxides with different cations $(\mathrm{Mg}, \mathrm{Co}, \mathrm{Ni}, \mathrm{Al})$, decomposition and reformation of mixed metal oxides to layered structures. Cent. Eur. J. Chem. 2011, 9, 275-282. [CrossRef]

23. Gao, Z.; Sasaki, K.; Qiu, X. Structural Memory Effect of Mg-Al and Zn-Al layered Double Hydroxides in the Presence of Different Natural Humic Acids: Process and Mechanism. Langmuir 2018, 34, 5386-5395. [CrossRef] [PubMed]

24. Dos Santos, R.M.M.; Gonçalves, R.G.L.; Constantino, V.R.L.; da Costa, L.M.; da Silva, L.H.M.; Tronto, J.; Pinto, F.G. Removal of Acid Green 68:1 from aqueous solutions by calcined and uncalcined layered double hydroxides. Appl. Clay Sci. 2013, 80-81, 189-195. [CrossRef]

25. Ni, Z.-M.; Xia, S.-J.; Wang, L.-G.; Xing, F.-F.; Pan, G.-X. Treatment of methyl orange by calcined layered double hydroxides in aqueous solution: Adsorption property and kinetic studies. J. Colloid Interface Sci. 2007, 316, 284-291. [CrossRef] [PubMed]

26. Hobbs, C.; Jaskaniec, S.; McCarthy, E.K.; Downing, C.; Opelt, K.; Güth, K.; Shmeliov, A.; Mourad, M.C.D.; Mandel, K.; Nicolosi, V. Structural transformation of layered double hydroxides: an in situ TEM analysis. npj 2D Mater. Appl. 2018, 2, 4. [CrossRef] 
27. Wong, F.; Buchheit, R.G. Utilizing the structural memory effect of layered double hydroxides for sensing water uptake in organic coatings. Prog. Org. Coatings 2004, 51, 91-102. [CrossRef]

28. Theiss, F.L.; Ayoko, G.A.; Frost, R.L. Removal of boron species by layered double hydroxides: A review. J. Colloid Interface Sci. 2013, 402, 114-121. [CrossRef] [PubMed]

29. Silva, I.G.N.; Rodrigues, L.C.V.; Souza, E.R.; Kai, J.; Felinto, M.C.F.C.; Hölsä, J.; Brito, H.F.; Malta, O.L. Low temperature synthesis and optical properties of the $\mathrm{R}_{2} \mathrm{O}_{3}: \mathrm{Eu}^{3+}$ nanophosphors $\left(\mathrm{R}^{3+}: \mathrm{Y}, \mathrm{Gd}\right.$ and $\left.\mathrm{Lu}\right)$ using TMA complexes as precursors. Opt. Mater. 2015, 40, 41-48. [CrossRef]

30. Marappa, S.; Radha, S.; Kamath, P.V. Nitrate-intercalated layered double hydroxides - Structure model, order, and disorder. Eur. J. Inorg. Chem. 2013, 2013, 2122-2128. [CrossRef]

31. Mokhtar, M.; Inayat, A.; Ofili, J.; Schwieger, W. Thermal decomposition, gas phase hydration and liquid phase reconstruction in the system $\mathrm{Mg} / \mathrm{Al}$ hydrotalcite/mixed oxide: A comparative study. Appl. Clay Sci. 2010, 50, 176-181. [CrossRef]

32. Valente, J.S.; Rodriguez-Gattorno, G.; Valle-Orta, M.; Torres-Garcia, E. Thermal decomposition kinetics of MgAl layered double hydroxides. Mater. Chem. Phys. 2012, 133, 621-629. [CrossRef]

33. Zhao, X.; Zhang, F.; Xu, S.; Evans, D.G.; Duan, X. From layered double hydroxides to ZnO-based mixed metal oxides by thermal decomposition: Transformation mechanism and UV-blocking properties of the product. Chem. Mater. 2010, 22, 3933-3942. [CrossRef]

34. Millange, F.; Walton, R.I.; O'Hare, D. Time-resolved in situ X-ray diffraction study of the liquid-phase reconstruction of $\mathrm{Mg}-\mathrm{Al}-$ carbonate hydrotalcite-like compounds. J. Mater. Chem. 2000, 10, 1713-1720. [CrossRef]

35. Silva, I.G.N.; Morais, A.F.; Brito, H.F.; Mustafa, D. $\mathrm{Y}_{2} \mathrm{O}_{2} \mathrm{SO}_{4}: \mathrm{Eu}^{3+}$ nano-luminophore obtained by low temperature thermolysis of trivalent rare earth 5-sulfoisophthalate precursors. Ceram. Int. 2018, 44, 15700-15705. [CrossRef]

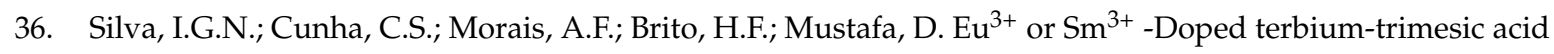
MOFs: Highly efficient energy transfer anhydrous luminophors. Opt. Mater. 2018, 84, 123-129. [CrossRef]

37. Lima, S.A.M.; Sigoli, F.A.; Davolos, M.R.; Jafelicci, M. Europium(III)-containing zinc oxide from Pechini method. J. Alloys Compd. 2002, 344, 280-284. [CrossRef]

38. Kumar, M.; Seshagiri, T.K.; Mohapatra, M.; Natarajan, V.; Godbole, S.V. Synthesis, characterization and studies of radiative properties on $\mathrm{Eu}^{3+}$-doped $\mathrm{ZnAl}_{2} \mathrm{O}_{4}$. J. Lumin. 2012, 132, 2810-2816. [CrossRef]

39. García-Hipólito, M.; Hernández-Pérez, C.; Alvarez-Fregoso, O.; Martínez, E.; Guzmán-Mendoza, J.; Falcony, C. Characterization of europium doped zinc aluminate luminescent coatings synthesized by ultrasonic spray pyrolysis process. Opt. Mater. 2003, 22, 345-351. [CrossRef]

40. Liu, K.; You, H.; Zheng, Y.; Jia, G.; Zhang, L.; Huang, Y.; Yang, M.; Song, Y.; Zhang, H. Facile shape-controlled synthesis of luminescent europium benzene-1,3,5-tricarboxylate architectures at room temperature. CrystEngComm 2009, 11, 2622-2628. [CrossRef]

41. Silva, I.G.N.; Mustafa, D.; Andreoli, B.; Felinto, M.C.F.C.; Malta, O.L.; Brito, H.F. Highly luminescent $\mathrm{Eu}^{3+}$-doped benzenetricarboxylate based materials. J. Lumin. 2016, 170, 364-368. [CrossRef]

42. Silva, I.G.N.; Mustafa, D.; Felinto, M.C.F.C.; Faustino, W.M.; Teotonio, E.E.S.; Malta, O.L.; Brito, H.F. Low Temperature Synthesis of Luminescent $\mathrm{RE}_{2} \mathrm{O}_{3}: \mathrm{Eu}^{3+}$ Nanomaterials Using Trimellitic Acid Precursors. J. Braz. Chem. Soc. 2015, 26, 2629-2639. [CrossRef]

43. Karbowiak, M.; Zych, E.; H ls, J. Crystal-field analysis of $\mathrm{Eu}^{3+}$ in $\mathrm{Lu}_{2} \mathrm{O}_{3}$. J. Phys. Condens. Matter 2003, 15, 2169-2181. [CrossRef]

44. Brito, H.F.; Malta, O.M.L.; Felinto, M.C.F.C.; Teotonio, E.E.S. Luminescence Phenomena Involving Metal Enolates. In PATAI'S Chemistry of Functional Groups; John Wiley \& Sons, Ltd.: Chichester, UK, 2010; pp. 131-184. ISBN 9780470061688.

45. Gollakota, P.; Dhawan, A.; Wellenius, P.; Lunardi, L.M.; Muth, J.F.; Saripalli, Y.N.; Peng, H.Y.; Everitt, H.O. Optical characterization of Eu-doped $\beta-\mathrm{Ga}_{2} \mathrm{O}_{3}$ thin films. Appl. Phys. Lett. 2006, 88, 221906. [CrossRef]

46. Trojan-Piegza, J.; Zych, E.; Hreniak, D.; Strek, W.; Kepinski, L. Structural and spectroscopic characterization of $\mathrm{Lu}_{2} \mathrm{O}_{3}$ :Eu nanocrystalline spherical particles. J. Phys. Condens. Matter 2004, 16, 6983-6994. [CrossRef] 
47. Zych, E. Concentration dependence of energy transfer between $\mathrm{Eu}^{3+}$ ions occupying two symmetry sites in $\mathrm{Lu}_{2} \mathrm{O}_{3}$. J. Phys. Condens. Matter 2002, 14, 5637-5650. [CrossRef]

48. Mustafa, D.; Silva, I.G.N.; Bajpe, S.R.; Martens, J.A.; Kirschhock, C.E.A.; Breynaert, E.; Brito, H.F. Eu@COK-16, a host sensitized, hybrid luminescent metal-organic framework. Dalt. Trans. 2014, 43, 13480-13484. [CrossRef] [PubMed] 